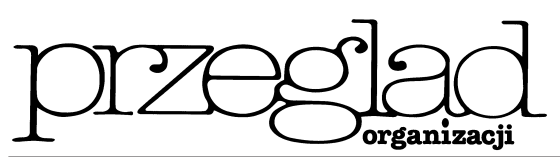

\title{
Kapitał prywatny jako źródło finansowania innowacji
}

https://doi.org/10.33141/po.2005.10.09

Krzysztof Janasz
Przegląd Organizacji, Nr 10 (789), 2005, ss. 37-39 www.przegladorganizacji.pl Towarzystwo Naukowe Organizacji i Kierownictwa (TNOiK)
Pojęcie kapitału stanowi jedną z najbardziej wieloznacznych kategorii, która jest używana w ujęciu zarówno makroekonomicznym, jak i mezoekonomicznym i mikroekonomicznym oraz odnoszona do całej gospodarki lub podmiotów gospodarczych.

Poziom innowacyjności w Polsce, pomimo wolno rosnącego zaangażowania różnych środków finansowych, jest $\mathrm{w}$ dalszym ciągu niewystarczający, za co odpowiadają między innymi słabo rozwinięte uregulowania prawne. Najistotniejszy jednak problem stanowi brak właściwego systemu instrumentów finansowych (systemu finansowania), który wynika z niedostatecznego udziału kapitału prywatnego służącego do finansowania działalności innowacyjnej.

Jednym z najważniejszych czynników, który warunkuje opłacalność oraz efektywność projektu innowacyjnego i równie często jego realizację, jest zamknięcie finansowe danego przedsięwzięcial ${ }^{1)}$.

Dobór struktury finansowania w ramach udziałów kapitałowych wymaga odpowiedzi na następujące pytania ${ }^{2)}$ :

- jak zorganizować i finansować przedsięwzięcie, - jak zarządzaći kontrolować realizację przedsięwzięcia,

- jak rozwiązywać spory między sponsorami a inwestorami kapitałowymi,

- jak zakończyć dany projekt?

W gospodarce rynkowej tworzenie i przepływy kapitałów pieniężnych są siłą pobudzająca działalność i rozwój gospodarczy. Dlatego też rynek finansowy, gdzie tworzy się kapitały pieniężne, jest podstawowym elementem systemu gospodarczego.

Efektywnie działający rynek finansowy może poprawić położenie wszystkich podmiotów na nim funkcjonujących. Niezmierne ważną rolę pełnią w tym względzie instrumenty rynku finansowego, które odgrywają ogromną rolę $\mathrm{w}$ finansowaniu działalności innowacyjnej.

W ramach rynku finansowego można wyróżnić następujące jego elementy (najbardziej klasyczny podział):

- rynek depozytowy,

- rynek kredytowy,

- rynek pieniężny,

- rynek kapitałowy,

- rynek walutowy,

- rynek pozabilansowych instrumentów finansowych (FRA).

Wymienione rynki w warunkach wolnej konkurencji wzajemnie się przenikaja i sa ze soba ściśle powiązane. Mówi się, że rynków finansowych jest tak wiele, jak wiele jest różnych rodzajów instrumentów finansowych. Stąd też na wyżej wymienionych rynkach przedsiębiorstwa moga zdobywać potrzebny kapitał na działalność rozwojową.

Najbardziej rozpowszechnioną metodą zdobycia potrzebnego kapitału na rynkach finansowych, a szczególnie na rynku kapitałowym, jest emisja instrumentu dłużnego, takiego jak obligacja. Obligacje to papiery wartościowe emitowane przez różne podmioty w celu pozyskania środków pieniężnych do finansowania określonych celów. Emitent zobowiązuje się do regulowania płatności odsetkowych określonych w dniu emisji papieru wartościowego oraz do spłaty pożyczki posiadaczowi obligacji w dniu jej wykupu. Obligacje sa $\mathrm{z}$ reguły papierami wartościowymi na okaziciela, co powoduje, że są produktem finansowym łatwo zbywalnym na rynku. Emitentami obligacji mogą być rządy i instytucje rządowe, przedsiębiorstwa i korporacje przemysłowe oraz banki. Kupujaccymi obligacje sa zwykle indywidualni inwestorzy, fundusze emerytalne, towarzystwa ubezpieczeniowe, banki, rządy oraz przedsiębiorstwa ${ }^{3)}$.

Drugą metodą zwiększania swojego kapitału jest emisja akcji. Akcja jest papierem wartościowym udziałowym. Jako papier wartościowy stwierdza udział jego posiadacza w spółce akcyjnej, a tym samym w jej kapitale. Dochód z akcji składa się z dwóch elementów ${ }^{4)}$ : - bieżącego kursu rynkowego danego waloru,

- wypłacanej przez firmę (emitenta) dywidendy z wypracowanych przez nią zysków.

Ważnym zagadnieniem dla inwestorów, jak i emitentów jest określenie ceny akcji. Dla inwestora informacja taka jest niezbędna w celu ustalenia, czy inwestowanie w akcje danej firmy będzie dla niego opłacalne w porównaniu z innymi źródłami inwestowania. Natomiast dla emitenta jest to także bardzo ważne, gdyż chce on zawsze poznać przyszłe tendencje kształtowania się kursów jego akcji, by móc na przykład odpowiednio wcześniej przygotować nową emisję akcji.

Kolejną niezmiernie ważną formą pozyskiwania kapitału jest rynek pieniężny ze swoimi instrumentami. Wyróżnia się dwa podstawowe kryteria klasyfikacji instrumentów rynku pieniężnego. Podstawę pierwszego podziału stanowi rozróżnienie, czy instrument jest zbywalny, czy też nie ${ }^{5}$.

Stosując to kryterium możemy wyróżnić:

- depozyty rynku pieniężnego,

- papiery zbywalne.

Drugie kryterium podziału dotyczy sposobu, w jaki przynoszą one dochód. Wyróżniamy tutaj dwie kategorie instrumentów ${ }^{6}$ : 
- instrumenty kuponowe (depozyty rynku pieniężnego, certyfikaty depozytowe, umowy odkupu), - instrumenty dyskontowe (bony skarbowe, weksle, bony komercyjne)

Z kolei do tradycyjnych form finansowania przedsięwzięć innowacyjnych finansowanych przez kapitał prywatny możemy także zaliczyć franchising i leasing. Pod koniec lat 50. ub. wieku w Stanach Zjednoczonych Ameryki Północnej nastąpił dynamiczny rozwój innowacji finansowej określanej jako venture capital ${ }^{7}$.

Venture capital jest uważany za specyficzną formę finansowania inwestycji i w ostatnim okresie innowacji. Ta forma wykorzystuje typowo rynkowe podejście do problemu. Venture capital to kapitał wysokiego ryzyka. Pojęcie to definiuje się jako jedna z instytucji rynku kapitałowego, która finansuje nowe przedsięwzięcia gospodarcze lub zapewnia środki finansowe na przedsięwzięcia o znacznym potencjale wzrostowym, ale jednocześnie o niskim poziomie dojrzałości ekonomicznej ${ }^{8}$.

Sektor venture capital istnieje w Polsce od blisko 10 lat, ponieważ dopiero w II połowie lat 90. ub. wieku wraz ze wzrostem wiarygodności polskiej gospodarki pojawili się w naszym kraju przedstawiciele dużych zachodnich funduszy typu venture capital. Obecnie funkcjonuje w Polsce 35 przedsiębiorstw venture capital, których inwestycje w latach 1998-2000 osiągnęły wartość 482 mln euro, co oczywiście nie jest wartością satysfakcjonującą ${ }^{9)}$.

Istotą działalności form venture capital jest wspomaganie zarządzania, formowanie bazy założycielskiej i faz wzrostu nowych przedsięwzięć innowacyjnych przez zapewnienie środków finansowych i ewentualnego doradztwa zarządczego ${ }^{10)}$.

Cele realizowane za pomocąventure capital są rozmaite. Może to być zdobycie środków na założenie firmy, na sfinansowanie rozwoju, czy na wprowadzenie innowacji.

We wrześniu 2004 roku pojawił się projekt ustawy o wspieraniu działalności innowacyjnej ${ }^{11)}$. Ustawa ta regulować ma formy wspierania działalności innowacyjnej. Należy przez to rozumieć udzielanie pomocy publicznej przedsiębiorstwom zajmującym się działalnością innowacyjną w formie kredytu technologicznego, ulg i zwolnień podatkowych, przyspieszonej amortyzacji. Przewidywane są także rozwiązania organizacyjno-prawne służące do racjonalizacji działalności innowacyjnej ${ }^{12)}$.

Tworzenie tzw. gospodarki opartej na wiedzy uważa się często za sposób na zwiększenie konkurencyjności ekonomicznej Polski. Wymaga to jednak wielu zmian, szczególnie w systemie finansowania, czyli znacznie większego udziału kapitału prywatnego, a także w funkcjonowaniu rynków finansowych oraz kwalifikacjach przedsiębiorców i inwestorów. Chodzi tu głównie o wyeliminowanie luki kapitałowej i kompetencyjnej, która ogranicza inwestycje prywatne w powstające i rozwijające się przedsiębiorstwa, stosujące najnowocześniejsze rozwiązania techniczne i technologiczne oraz komercyjnie wykorzystujace opracowane w polskich ośrodkach naukowo-badawczych innowacyjne rozwiązania techniczne ${ }^{13)}$.

Mało jest również w Polsce indywidualnych inwestorów prywatnych. Można do nich zaliczyć sieć in- westorów prywatnych skupionych wokół Akceleratora Technologii Fundacji Centrum Innowacji FIRE w Warszawie, a także działające w Bydgoszczy Polskie Stowarzyszenie Business Angels (EBAN). Liczba takich inwestorów jednak powoli rośnie, ale relatywnie niewielu z nich decyduje się na zaangażowanie w projekty komercyjnego wykorzystania rozwiązań technologicznych. Wiąże się to niewątpliwie z faktem, że inwestorzy ci są ciągle na wczesnym etapie rozwoju, a ich potencjał finansowy i intelektualny nie jest dostatecznie skoncentrowany ${ }^{14)}$.

Jak wspomniano wyżej powiązania $\mathrm{z}$ inwestorami i instytucjami będącymi źródłem kapitałów, stanowiące kolejny wyznacznik rynkowej pozycji danego przedsiębiorstwa, wiążą się nieodzownie z rynkiem finansowym. W warunkach ograniczonej dostępności środków i wysokiej konkurencji towarzyszącej ich pozyskaniu, trudno przecenić znaczenie związków przedsiębiorstwa z uczestnikami rynków pieniężnego i kapitałowego. Możliwości uzyskania środków pieniężnych przez kredyt, emisję obligacji, akcji, jak też poprzez niektóre instrumenty pochodne, niejednokrotnie decydują o rzeczywistych możliwościach przetrwania i rozwoju przedsiębiorstw ${ }^{15)}$.

Niezmiernie istotny jest fakt, że Polska w ostatnich latach stała się pod wieloma względami dobrym rynkiem dla inwestycji private equity/venture capital ${ }^{16}$. Są to inwestycje na niepublicznym rynku kapitałowym mające na celu osiąnnięcie średnio- i długoterminowych zysków z przyrostu wartości kapitału. Inwestycje te mogą być wykorzystane na rozwój nowych produktów i technologii, zwiększenie kapitału obrotowego, przejmowanie spółek lub też na poprawę i wzmocnienie bilansu firmy. Natomiast wcześniej omówiony venture capital jest jedną $\mathrm{z}$ odmian private equity. Są to inwestycje dokonywane we wczesnych stadiach rozwojów przedsiębiorstw, mające na celu uruchomienie działalności nowej firmy lub też wejście jej na nowe i atrakcyjne rynki.

W Polsce dominuje sektor prywatny, który w 2002 roku wytworzył $77 \%$ produkcji sprzedanej przemysłu $^{17)}$, spadła inflacja, wzrost gospodarczy za II kwartał 2004 roku w ujęciu rocznym wyniósł $6,1 \%$ PKB, co sytuuje nasz kraj na trzecim miejscu w gronie wszystkich krajów Unii Europejskiej. Należy przypuszczać, że kolejne lata pozwolą na przyspieszenie dotychczasowych trendów. Członkostwo Polski w Unii Europejskiej pozwoli niewątpliwie firmom zarządzającym funduszami private equity na jeszcze większe zaangażowanie się na naszym rynku. W najbliższym czasie można spodziewać się następujących zmian ${ }^{18)}$ :

- wyeliminowania barier w handlu z krajami UE, co da bodziec rozwojowy spółkom eksportującym na te rynki;

- napływu funduszy strukturalnych UE, co powinno poprawić infrastrukturę oraz przyspieszyć rozwój gospodarczy;

- prawdopodobnego przenoszenia produkcji przez międzynarodowe firmy do regionu bogatego w wykwalifikowana, lecz tańszą siłę roboczą;

- wejścia na rynki Europy Środkowo-Wschodniej funduszy inwestujących wyłącznie w krajach Unii Europejskiej, co może zwiększyć sumę inwestycji zagranicznych w Polsce. 
Przyjrzyjmy się, jak w ostatnim okresie, jeszcze przed wejściem Polski do struktur UE, radziły sobie inwestycje funduszy private equity na naszym rynku. Według badania przeprowadzonego przez European Private Equity and Venture Capital Association (EVCA), fundusze te zainwestowały $529 \mathrm{mln}$ PLN w 2002 roku, a więc o 37\% więcej niż w 2001 roku, kiedy to suma inwestycji wyniosła $386 \mathrm{mln}$ PLN. Na wynik ten złożyły się zarówno inwestycje firm działajacych w Polsce, jak i zagranicznych firm zarzadzajacych funduszami ${ }^{19)}$. Te pierwsze zainwestowały 422 mln PLN w 2002 roku, o 25\% więcej niż w 2001 roku, który zamknął się kwotą 377 mln PLN. Inwestycje firm zagranicznych wyniosły $107 \mathrm{mln}$ PLN w porównaniu z $49 \mathrm{mln}$ PLN w 2001 roku, co daje wzrost o prawie $120 \%$. Można więc zauważyć, że Polska była atrakcyjnym kierunkiem inwestycji dla funduszy private equity. Widać było również oznaki ożywienia po okresie osłabienia aktywności inwestycyjnej w 2001 roku. Warto dodać, że łączna suma inwestycji w Polsce była wyższa niż w kilku krajach UE, między innymi Irlandii, Austrii, Portugalii czy Grecji. W 2002 roku zaobserwowano widoczną zmianę kierunków inwestowania wśród polskich firm zarządzajacych funduszami. Podobnie jak w całej Europie nastąpił zwrot w kierunku sektora dóbr konsumpcyjnych, gdzie trafiło 159 mln PLN, co stanowiło 35\% całości środków zainwestowanych w Polsce i w krajach regionu. Była to radykalna zmiana, zważywszy, że w 2001 roku jedynie 49 mln PLN trafiło do tego sektora. Natomiast dział telekomunikacji i mediów, który w 2001 roku cieszył się największym zainteresowaniem funduszy - 256 mln PLN i 46\% całości, przyciagnał jedynie 63 mln PLN, tj. 14\% całości w 2002 roku. Znaczny spadek inwestycji dotyczył również sektora zaawansowanych technologii, który przyciagnął w 2002 roku jedynie 8\% (36 mln PLN) w porównaniu z 34\%186 mln w 2001 roku $^{20)}$.

Należy sądzić, że z pewnością private equity będzie pełnić ważną rolę w Polsce oraz całym regionie, niezależnie od tego, jaka droga zostanie obrana i jakie będą nowe wyzwania.

Private equity/venture capital mają niewątpliwa przewage nad innymi sposobami finansowania działalności innowacyjnej w kilku ważnych punktach. Jeden z najpopularniejszych sposobów finansowania kredyt bankowy wymaga posiadania wysokich zabezpieczeń i obciąża przedsiębiorstwo koniecznością terminowych spłat, co wymaga dość wysokiej płynności danej firmy. Trudno jest ją utrzymać nowej lub obciążonej długiem firmie. Natomiast tzw. inwestor działowy z reguły przejmuje kontrolę nad nabywaną firma, włącza ją w swoje struktury i dopasowuje do celów własnej działalności.

Dostęp do kapitału jawi się we współczesnej gospodarce rynkowej jako jeden z najważniejszych elementów strategii przedsiębiorstwa, które jest zorientowane na szeroko pojęte innowacje. To kryterium ma dwa wymiary: prawny oraz ekonomiczno-finansowy. Aby mieć dostęp do środków finansowych $\mathrm{z}$ branego pod uwagę źródła, należy stawić wyzwanie obu wymiarom. Pierwszy z nich od razu eliminuje możliwość emisji akcji przez podmioty nie będace spółkami akcyjnymi oraz możliwość emisji obligacji przez podmioty nie wymienione w ustawie o obligacjach, pozbawiajacc je szansy zdobycia środków. Natomiast wymiar ekonomiczno-finansowy, który warunkuje dostęp do określonych źródeł finansowania wiąże się z koniecznością udokumentowania odpowiednio - przeszłego, teraźniejszego i przyszłego - standingu finansowego ${ }^{21}$.

Aby efektywnie prowadzić i rozwijać działalność innowacyjna potrzebne sa środki pieniężne, do których wciąż przedsiębiorstwa mają utrudniony dostęp. Poprawę sytuacji może spowodować wejście Polski w struktury UE. Najważniejsze jednak wydaje się jak największe zaangażowanie się kapitału prywatnego i jego form finansowania $\mathrm{w}$ działalność innowacyjna i rozwojową.

dr Krzysztof Janasz Katedra Makroekonomii Uniwersytet Szczeciński

\section{PRZYPISY}

1) Por. K. BRZOZOWSKA, Kapitat prywatny $w$ finansowaniu projektów infrastruktury gospodarczej na zasadach project finance, Wydawnictwo Akademii Rolniczej w Szczecinie, Szczecin 2003, s. 124.

2) Ibidem, s. 125.

3) Zob. K. JANASZ, Rynek finansowy, [w:] Podstawy teorii i polityki makroekonomicznej, pod red. Cz. SUŁKOWSKIEGO, Wydawnictwo ZAPOL, Szczecin 2004, s. 130.

Ibidem, s. 129.

5) K. JANASZ, Kapitat prywatny $w$ finansowaniu dziatalności innowacyjnej przedsiębiorstw $w$ procesie transformacji, [w:] Innowacje $w$ działalności przedsiębiorstw $w$ integracji $z$ Unia Europejska, praca zbiorowa pod red. W. JANASZA, Difin, Warszawa 2005, s. 221.

6) Szerzej na temat finansowania innowacji instrumentami rynku pieniężnego zob. K. JANASZ, Źródta i sposoby finansowania innowacji w przedsiębiorstwie, [w:] Innowacje $w$ rozwoju przedsiębiorczości $w$ procesie transformacji, praca zbiorowa pod red. W. JANASZA, Difin, Warszawa 2004 , s. $109-114$

7) Por. J. OSTASZEWSKI, Źródta pozyskiwania kapitatu przez spótke akcyjna, Difin, Warszawa 2000, s. 127.

8) K. JANASZ, Źródta finansowania innowacji, [w:] W. JANASZ, K. JANASZ, A. ŚWIADEK, J. WIŚNIEWSKA, Strategie innowacyjne przedsiebiorstw, Wydawnictwo Naukowe Uniwersytetu Szczecińskiego, Szczecin 2001, s. $422-423$.

9) J. JEŻAK, R. SAEATA, Fundusze venture capital jako źródto kapitału dla matych $i$ średnich przedsiębiorstw, [w:] Uwarunkowania przedsiębiorczości, praca pod red. K. JAREMCZUKA, Państwowa Wyższa Szkoła Zawodowa im. prof. S. Tarnowskiego w Tarnobrzegu, Tarnobrzeg 2004 , s. 335

10) Elementy strategii rozwoju przemystu, red. W. JANASZ. Wydawnictwo Naukowe Uniwersytetu Szczecińskiego, Szczecin 2000, s. 403.

11) Zob. K. JANASZ, Kapitat prywatny..., op.cit., s. 226-228.

12) Zob. projekt ustawy o wspieraniu działalności innowacyjnej oraz zmianie niektórych ustaw z 7.09.2004 r

13) Por. S.M. JANIK, Brakuje kapitatu $i$ umiejętności, , ,Rzeczpospolita" nr 232 z 2-3.10.2004 r, s. B4.

14) Ibidem.

15) C. SZUSZYŃSKI, Restrukturyzacja, konsolidacja, globalizacja a przedsiębiorstwo, Polskie Wydawnictwo Ekonomiczne, Warszawa 2003, s. 36.

16) Por. K. JANASZ, Kapitat prywatny..., op.cit., s. 228-229.

17) Zob. Rocznik Statystyczny 2002, s. 334.

18) Rocznik 2003 - Polskie Stowarzyszenie Inwestorów Kapitatowych, Warszawa 2003, s. 33.

19) Ibidem, s. 37.

20) Ibidem, s. 41-43.

21) S. WYMYSŁOWSKI, Kryteria wyboru źródet finansowania działalności rozwojowej - teoria i praktyka, [w:] Finansowe uwarunkowania rozwoju organizacji gospodarczych, red. naukowa J. TURYNA, W. SZCZECSNY, Difin, Warszawa 2004, s. 677-678. 